\title{
Claim Settlement Process of Life Insurance Services - A Case study of ICICI Prudential Life Insurance Company
}

\author{
Rajesh K. Yadav ${ }^{1, a}$, Sarvesh Mohania ${ }^{2, b}$ \\ ${ }^{1}$ Maxim Institute of Technology, Bhopal (M.P.), India \\ ${ }^{2}$ CRIM (UTD), Barkatullah University, Bhopal (M.P.), India \\ ${ }^{a, b}$ E-mail address: drrajeshkyadav@yahoo.com , sarveshmohania@yahoo.com
}

\begin{abstract}
Life insurance is mainly taken to cover up risk of death/disability in term of monetary terms and secondary for the purpose of better return as investment option. Claims are filed at the time of maturity or in case of death/disability. The study focuses on the claim settlement process of life insurance services of ICICI prudential life insurance company. With the increasing numbers of policies, numbers of claims are also increasing in ICICI prudential life insurance company. Therefore it is very much essential to have simple and clear claim settlement process. The study is based on the secondary data collected from IRDA and research papers from various journals. The study concluded that in ICICI prudential life insurance company with their "Customer First" approach efficiently perform their claim settlement process.
\end{abstract}

Keywords: Claim Settlement; Life Insurance; ICICI Prudential Life Insurance Company

\section{INTRODUCTION}

Insurance is a protection against economical loss arising due to an unexpected event. Insurance contract is a contract by which one party called the insurer promises to save the other party, the insured on payment of consideration known as the premium. A right of insured to receive the amount secured under the policy of insurance contract promised by insurer is called claim. Claims can be maturity claims arise because of survival up to the end of the policy term i.e. to the date of maturity, survival benefits due to survival up to a specified period during the term, death claims arise due to death of the life assured during the term. Policy holders or nominees must first file an insurance claim before any money can be provided. An insurance claim is provided by an insurance company .The insurance company may or may not approve the claim, based on their own assessment of the condition under which claim is made. Claim settlement is one of the important part of life insurance services. It said that really testing of any insurance is done at the time of the claims. Any policyholder expects to have fair and hassle free claim settlement process at the time of need. Claim settlement process normally involves multiple systems, multiple processes, and multiple channels. Today insurance companies have improved their claim settlement process, controlled claim expenses and focuses towards improving customer satisfaction. 
ICICI prudential life insurance company is one of the first private life insurance company set up in India in December 2000 and maintaining its lead over private sector life insurance companies.

\section{LIFE INSURANCE IN INDIA}

In India, insurance business started 150 years ago. With the establishment of the Oriental Life insurance company in Calcutta, the business of life insurance in India was started in 1818. It was started by Mr Bipin Behari Dasgupta and Europeans living in India were their primary customers. The first native insurance provider in India was formed in 1870 with the name Bombay Mutual Life Assurance Society.In 1938, Insurance Act was passed and department of insurance under the authority of superintendent of Insurance was established for the administration of the Insurance Act. In 1939 - 1955 uncovers absence of trust which was the foundation of life insurance business and nationalization got vital. LIC of India was formed in 1956 by an Act of parliament and is fully owned by Government of India. As on till date there are total 24 Life Insurance Companies in India. Life Insurance Corporation of India, ICICI Prudential Life Insurance Company, Bajaj Allianz Life Insurance Company, and HDFC Life Insurance Company Etc., are the few names of Public sector and Private sector companies. [6]

Life insurance is mainly taken for two objectives, first is for risk coverage and second is for the investment objective.

i) Risk coverage: - Lump sum payment is provided if specific event occurred.

ii) Investment: -Money is invested with a motive of getting greater return.

Primary purpose of any insurance service is to provide risk against uncertainty. For this risk management, policy holder regularly pays insurance premium to the insurance providing company. However, the risk is intangible and seldom is the need for a risk coverage felt by an individual customer, therefore an extra effort needed to make the customer understand the need for insurance. [10]

\section{ICICI PRUDENTIAL LIFE INSURANCE COMPANY}

ICICI Prudential Life Insurance Company is one of India's leading private life insurance companies which provide insurance product range for individuals and groups. ICICI Prudential Life Insurance Company is a joint venture between ICICI Bank LTD, India's largest private sector bank and Prudential Plc established in 1948 in London is an international retail financial services group having operation in Asia, United States and United Kingdom. ICICI Prudential Life Insurance Company after receiving approval from Insurance Regulatory Development Authority (IRDA) in December 2000 was amongst the first private sector Insurance companies to start their operation.

In the ICICI Prudential Life Insurance Company, ICICI Bank Ltd. holds $74.00 \%$ and Prudential Plc holds $26.00 \%$ of equity in the joint venture. ICICI Bank Ltd. is the largest private sector bank and the second largest bank in India. It is currently functioning in 19 countries, including India. Prudential Plc is one of the best retail financial services providers with approximately 25 million customers. It is leading life insurer in Asia with presences in 
the 12 markets which include locations like India, Hong Kong, Malaysia, Vietnam, Singapore, Philippines and Indonesia.

ICICI Prudential Life Insurance Company has a strong network of approximately 1,400 offices and over 1, 75,000 advisors as on till date. Customers have the advantage of customizing the plans. Its product portfolio includes solutions, which meet various customer needs such as Savings, Investment, Protection, Health and Pension.

\section{CLAIM SETTLEMENT PROCESS OF ICICI PRUDENTIAL LIFE INSURANCE COMPANY}

With the "Customer First" approach, ICICI Prudential Life Insurance Company tries to fulfill promise of early claim settlement to every customer along with transparency and quickness. They gave emphasis on earliest payment of genuine and legitimate claims, for that they review their claim process time to time.

They follow three steps claim settlement process:-

\section{Step One:}

Claim Intimation: - Policy Holder/Nominee intimate claims to the ICICI Prudential Life Company, Intimation can be done through following ways:

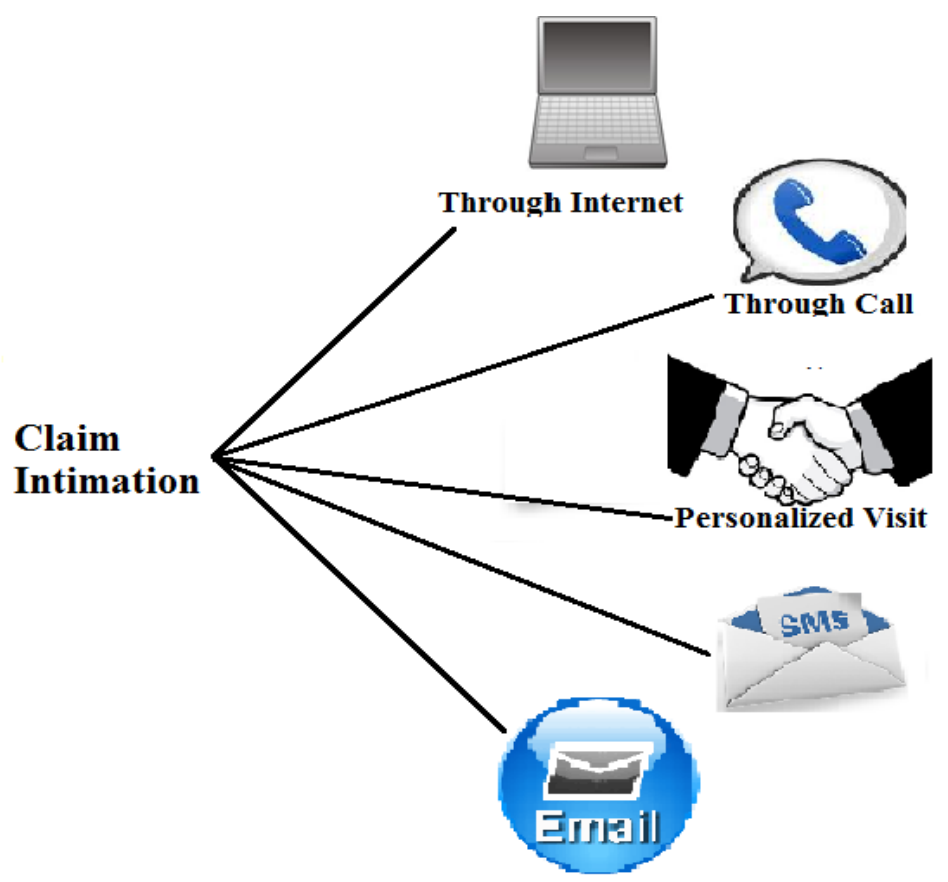

Fig. 1. Showing various mode of claim Intimation in ICICI Prudential Life Company. 
1. Through Internet: - Policy Holder/Nominee can intimate claims directly through the link available on the company's website. Claims registered through this mode are considered as verbal information which is not formally registered. For formally registering claims, one is required to file written intimation to concerned branch or to central claims team.

\section{ONLINE CLAIM INTIMATION}

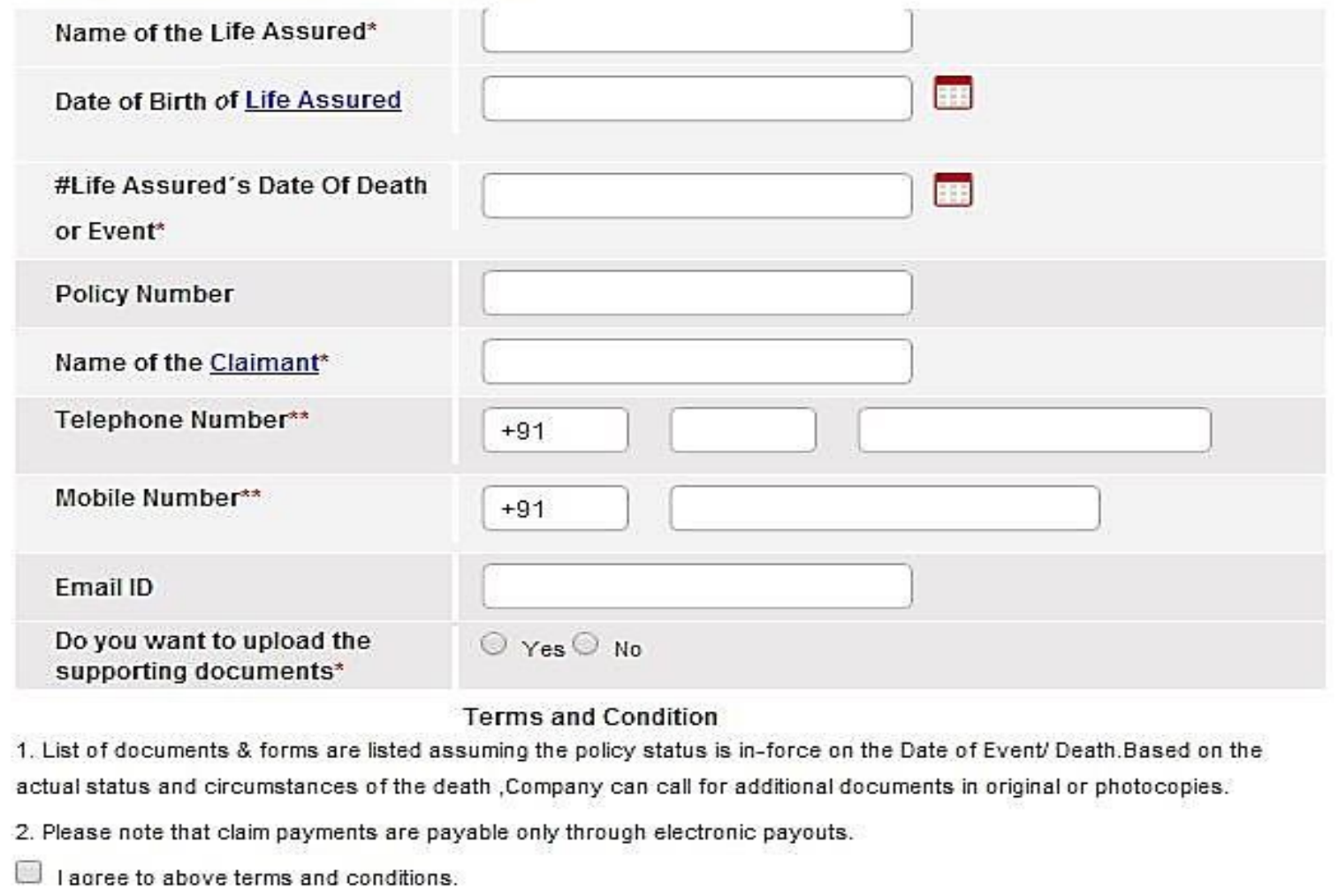

Fig. 2. Showing online mode of claim Intimation in ICICI Prudential Life Company.

2. Through Call: - Policy Holder/Nominee can intimate claims by calling on the available 24 X 7 customer care numbers. There are few toll free customer care numbers too. Claims registered through this mode are considered as verbal information which is not formally registered. For formally registering claims, one is required to file written intimation to concerned branch or to central claims team.

\section{Toll-free No: - 1860-266-7766}

3. Through personalized visit: - Policy Holder/Nominee can intimate claims to nearest branch of ICICI prudential Life Insurance Company or Corporate Claims Cell. Intimation should be in written form; this will be considered to formal intimation. There are more than 1400 numbers of branches all across in India.

4. Through SMS: - Policy Holder/Nominee can intimate claims by sending SMS to IClaim Services along with policy number to 56767. 


\section{SMS IClaim<space $>8$ digit policy no to 56767}

5. Through e-mail: - Policy Holder/Nominee can intimate claims by sending e-mail to the dedicated e-mail address for claim settlement process.

E-mail at: lifeline@iciciprulife.com

\section{Step Two: -}

Claim Processing: - In claim processing, dedicated claim care team analyses each claim in detail. On the basis of all records and proofs in connection with the claim, Claims are examined and settled by the company. Sometime if there are any pending documents then the requirement is raised within 8 calendar days from the date of receipt of claim intimation, company informs the claimant about the required documentation. For the better services, customers are provided support during their claim settlement process and for that following features are added on:

- Priority Claim Desk at ICICI Prudential Life Insurance Company's branches.

- Sending SMS at specified milestones

- Personalized Calling

- Reminder letters if required any documents

- Sending e-mail to the claimants/beneficiaries.

- 24X 7 Claim helpline number 1860-266-7766.

\section{Document Submission:-}

The Policy holder/Nominee can submit all required documents at following:-

- To the nearest ICICI Prudential Life Insurance Company branch

- Life claims cell / Health claims cell at:-

ICICI Prudential Life Insurance Company Ltd, BSEL tech, C- wing, 1st floor, Vashi, Navi Mumbai - 400703.

\section{Step Three:}

Claim Payment Decision: - Once all the required documents are submitted to the concern branch or claim cell and documentation is complete then on the basis of that decision regarding the payment of claim is taken within 10 days. If in any case claims require further verification, the claimant is informed about that. Whatever a decision is taken, claimant is informed with the help of written communication through letter.

\section{Payment to Policy Holder/Nominee as the case may be:}

If the claim raised in the insurance policy is maturity type and policy holder is still alive then the amount of the claim will be paid to the policy holder only.

In case of death, amount of claim will be paid to the Nominee.

Following person can be nominee: -

- The appointee (in case of minor nominee) or the nominee last recorded under the policy in case of policy on own life.

- If policy is not on own life then the proposer of the policy. 
- If the policy is assigned then assignee.

- In case of policy on own life for living benefit claims i.e. claims under disability, critical illness and major surgery rider, life assured himself/ herself.

\section{In case if there is no Nominee:}

If there is no Nominee for the claim amount of policy then such situation is called as "Open Title situation". Once ICICI prudential life insurance company accepted the claim and it is waiting for proof of title/ succession certificate issued by the competent court, the claim would be paid to the person specified in the given proof provided in competent court. In case if the ICICI prudential life insurance company accepted is waiting for such type of proof for the payment of claim, then the ICICI prudential life insurance company accepted will hold the claim amount and provide interest as directed by IRDA for holding period at the time of payment of claim. [1]

\section{CONCLUSION}

Claim settlement process need to be as per requirement of the customers, so that at the time of need, no customer should be suffered due complexity of the claim settlement process. Faster claim settlement process reduces the cost of processing any claim whereas multiple stages in the process should be avoided since it increases the cost of claim settlement. For increasing the speed, policyholders should be provided proper information on regular bases. ICICI prudential life insurance company is very much flexible and updated in their claim settlement process.

\section{References}

[1] Available from:

http://www.iciciprulife.com/public/Life-Claims/FAQ-claims.htm

[2] Chaudhary Sonika, Kiran Priti, International Journal of Management \& Business Studies 1(3) (2011) 146-150.

[3] Kotgiri Sushma K., Indian Journal of Research in Management, Business and Social Sciences 1(1) (2013) 62-66.

[4] Krishnan Bindu, The Journal of Insurance Institute of India XXXVI (2010) 49-57.

[5] Kumar Vineet, Kumari Poonam, International Journal of Business and Management Research 2(10) (2012) 515-517.

[6] Kumari T. Hymavathi, International Journal of Social Sciences Arts and Humanities 1(1) (2013) 7-14.

[7] Purusothaman Uma Rani, TRANS Asian Journal of Marketing \& Management Research 2(7) (2013) 26-36. 
[8] R. Nandagopal, J. Sekkizhar, M. Sathish, The Journal Contemporary Management Research 5(1) (2011) 59-67.

[9] Sharma Vikas, Chowhan Sudhinder Singh, Indian Journal of Applied Research 1(3) (2013) 93-94.

[10] Yadav Rajesh K. and Mohania Sarvesh, Indian Journal of Economics and Development 1(1) (2013) 29-37.

( Received 29 June 2014; accepted 06 July 2014 ) 